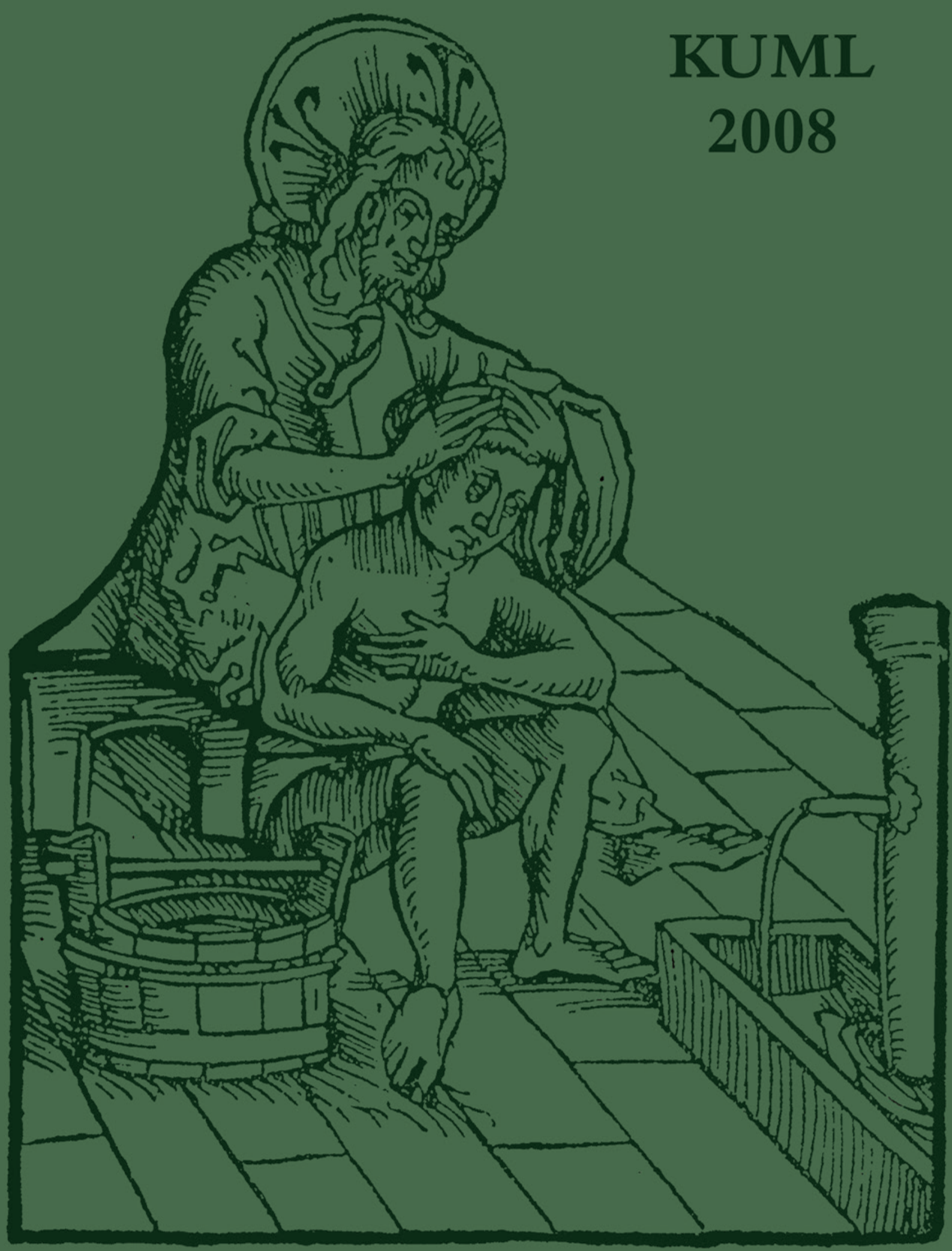




\section{KUML 2008 \\ Årbog for Jysk Arkæologisk Selskab}

With summaries in English

I kommission hos Aarhus Universitetsforlag 


\title{
Lindholm Høje Museet: Limfjordslandet
}

\author{
Af JEANETTE VARBERG
}

I september 2008 åbnede Lindholm Høje Museet nord for Ålborg en ny udstilling, som omfatter den nordjyske oldtid fra stenalder til vikingetid. Udstillingen har fået den velvalgte titel Limfjordslandet, og udstillingen tager den besøgende med på en rejse gennem 3000 år i det nære og lokale arkæologiske miljø omkring den store fjord. Det er de små historier med mennesket i centrum, som er udstillingens omdrejningspunkt, og dermed distancerer udstillingen sig fra andre kulturhistoriske udstillinger, hvor kronologien bestemmer farten frem for den menneskelige fortælling.

Udvidelsen på knap $1000 \mathrm{~m}^{2}$ består af fire elementer: Udstillingen, et amfiteatralsk auditorium (Aalborg Portland Salen), et formidlingsrum og en 3Danimeret installation af en sejlads i vikingeskib over Limfjorden. Udstillingen er etableret i samarbejde med Haastrup Arkitekter, som er en tegnestue med speciale i grafisk identitet, og kernen i deres koncepter er den kommunikative grafik til museale rum og oplevelsescentre.

Limfjordslandets oldtidshistorie bliver tematisk fortalt, men måske fordi fortiden altid huskes og fortælles lineært, og det forekommer os mennesker nemmest sådan, så er temaerne diskret indpasset i den arkæologiske kronologi, dog uden tematikken mister pusten.

Udstillingsudbygningen ligger i et forskudt plan i forhold til den gamle udstilling fra 1992. En bred trappe fører fra ankomstarealet ned mod den nye udstilling, og her åbner rummet sig i den første fortælling om stenalderens minedrift og serieproduktion af flintdolke. En blændende hvid kalkvæg, trykskærme og illustrationer formidler på bedste vis historien bag de fantastisk flotte flintdolke, der sandsynligvis repræsenterer det første vellykkede nordjyske eksporteventyr. Som gæst føler man sig informeret og underholdt uden at skulle læse særligt meget tekst. Kommunikationen mellem gæsten og udstillingsmedierne foregår på flere niveauer, og derfor er informationstilgangen let og elegant.

Fra den hvide væg træder man nærmere mosen, som henlægger i dæmpet belysning. Gulvet er lavet af polerede sorte sten, så gangen ud på den brede 
træbro føles som en vandring ud over mosens dybsorte vand. Tørvevægge og et skiftende moselandskab på bagvæggen skaber en fortættet stemning fra mosen, og montrer langs gangbroen understøtter historien om de mosefundne genstande. Det har ikke været muligt for udstillingsteamet at fremskaffe alle nordjyske mosefund, så i enkelte tilfælde er kopier brugt i stedet.

Moseliget af Borremosekvinden er ikke udstillingsegnet, og i stedet er hun udstillet som en brun silhuet på en vandret plexiglasplade i ca. halv størrelse. Det bliver måske en anelse for abstrakt og fortænkt, og det dæmpede lys gør, at man ikke rigtigt kan se, hvad tegningen forestiller ved første øjekast. Her kunne et almindeligt fotografi have været langt mere informativt - omend også noget mere traditionelt, end udstillingskonceptet lægger op til. Længere henne i udstillingsforløbet møder man hende igen, i en rekonstrueret form, hvor hendes ansigt er blevet modelleret efter en scanning af hendes mosefundne rester. Det er det ansigt, man husker - ikke brun farve på plexiglas.

Pragtfundet i mosen er Frøya. En træfigur fra bronzealderens slutning, hvis historie og betydning fortælles af en drengs stemme, der aktiveres, når man stiller sig et bestemt sted i udstillingen. Det er et sjovt greb at lade en fiktiv person fra fortiden fortælle om sine oplevelser i udstillingen. Det vækker fortiden til live. Og er man først opmærksom på, at lyden kan aktiveres, så opdager man, at den lydeffekt optræder flere steder i udstillingen.

Det er dog den samme dreng, der fortæller i de forskellige iscenesatte tidsaldre, og det kan godt virke forvirrende. Selvom han fortæller forskellige historier, der passer til udstillingstemaerne, så er det tydeligt, at det er den samme karakter, der fortæller. Derfor går noget af illusionen tabt. Det ville have virket så meget stærkere, hvis der var taget udgangspunkt i forskellige personer, både mænd, kvinder, børn og gamle. Eftersom formidlingen her tager springet ud i fiktionen, er det altafgørende at være tro mod genren og skabe en fuldstændig illusion for hvert tema.

Den lange udstillingshal bliver mere farverig, jo længere man bevæger sig ind gennem montrer, scenerier og stemningsgivende lærreder med Limfjordslandskaber. Dagliglivet er omdrejningspunktet, og man kommer tæt på mennesket i oldtiden. Der er ikke mange pragtsmykker eller montrer fyldt med store skatte, men til gengæld evner udstillingen at lade udefrakommende træde ind i fortidens liv. Det er sjældent at besøge en udstilling, hvor man i den grad ser fortidens mennesker i øjnene og føler, at det er en ligeværdig og nærværende person som dig og mig, der betragter dig tilbage igen - bare i en lidt besynderlig klædedragt.

Detaljerne i dagliglivet gør oldtiden nærværende og forståelig, og de rammer nogle gange fuldstændig uventet. Som i det halvt rekonstruerede jernalderhus, 
der omslutter fund fra brandtomten i Nørre Tranders. Hvis man på trykskærmen vælger information om branden, så er det ikke fakta, der toner frem på skærmen, men et inferno af ild og drengens råb efter dyrene, der pludselig omgiver dig. Teaterets effektfulde illusioner gengiver ildens rasende inferno, og det virker overraskende stærkt.

Samme uventede og legende tilgang til formidlingen optræder ved montren, der fortæller om jernalderens fremstilling af glasperler. Ved siden af montren kan man for en krone trække et bolsje i en lille kugleautomat. Bolsjerne har samme mønstre som glasperlerne i montren. Og mens man eftertænksomt knaser sit bolsje, så glemmer man ikke lige med det samme, at fremstillingen af glasperler er lidt det samme princip som fremstillingen af bolsjer.

Igen er det kommunikationen på mange niveauer og til flere sanser, der gør det her museumsbesøg til en anderledes oplevelse. Det er et formidlingsgreb, der frigør den arkæologiske fortælling fra tingenes magt og flytter livet ind i centrum. Haastrups arkitekters målsætning om grafisk identitet og kommunikation er til fulde kommet i spil i Lindholm Høje Museet.

Der er en verden til forskel mellem de to kulturhistoriske udstillinger, der er åbnet med få måneders mellemrum i 2008. Nationalmuseets nyopsætning af Danmarks Oldtid er strengt kronologisk opbygget med genstanden og fortidsskattene i centrum. Lindholm Høje Museet har ikke skyggen af den samme genstandsrigdom, men til gengæld fortælles oldtiden med udgangspunkt i mennesket. Nationalmuseet formidler den store nationale historie om Danmark i oldtiden på en fastlåst og traditionsbunden facon, hvor Lindholm Høje Museet formidler den lokale oldtid på en nytænkende og legesyg måde, der gør det ordinære exceptionelt og det lokale relevant for verden omkring.

De to udstillinger ligger i hver sin del af landet, men ideelt set burde de ligge i forlængelse af hinanden. Så man på en gang kunne blive indviet i den danske fortids mange skattes overvældende mængde og smukke detaljer og samtidig opleve at stå ansigt til ansigt med Limfjordslandets vindblæste mennesker.

Mennesker, som jeg nu føler, at jeg kender. Bortset fra præsten i Sebbersund. Drengen sagde hele tiden, at jeg skulle spørge præsten, hvis jeg var i tvivl om noget, og det er man vel altid - men jeg fandt ham aldrig. 